\title{
Expression of a novel carbonic anhydrase, CA XIII, in normal and neoplastic colorectal mucosa Laura Kummola1 ${ }^{1}$, Jonna M Hämäläinen ${ }^{1}$, Jyrki Kivelä2 ${ }^{2}$, Antti J Kivelä ${ }^{1}$, Juha Saarnio $^{3}$, Tuomo Karttunen ${ }^{4}$ and Seppo Parkkila*1,5
}

Address: ${ }^{1}$ Institute of Medical Technology, University of Tampere, and Tampere University Hospital, Tampere, Finland, ${ }^{2}$ Institute of Dentistry, University of Helsinki and Research Institute of Military Medicine, Central Military Hospital, Helsinki, Finland, ${ }^{3}$ Department of Surgery, University of Oulu, Oulu, Finland, ${ }^{4}$ Department of Pathology, University of Oulu, Oulu, Finland and ${ }^{5}$ Department of Clinical Chemistry, University of Oulu, Oulu, Finland

Email: Laura Kummola - laura.kummola@uta.fi; Jonna M Hämäläinen - jonna.hamalainen@uta.fi; Jyrki Kivelä - jyrki.kivela@fimnet.fi; Antti J Kivelä - antti.j.kivela@fimnet.fi; Juha Saarnio - juha.saarnio@oulu.fi; Tuomo Karttunen - tuomo.karttunen@oulu.fi; Seppo Parkkila* - seppo.parkkila@uta.fi

* Corresponding author

Published: 18 April 2005

BMC Cancer 2005, 5:4I doi:|0.|| 86/|47|-2407-5-4|
Received: 13 December 2004

Accepted: 18 April 2005

This article is available from: http://www.biomedcentral.com/I47I-2407/5/4I

(c) 2005 Kummola et al; licensee BioMed Central Ltd.

This is an Open Access article distributed under the terms of the Creative Commons Attribution License (http://creativecommons.org/licenses/by/2.0), which permits unrestricted use, distribution, and reproduction in any medium, provided the original work is properly cited.

\begin{abstract}
Background: Carbonic anhydrase (CA) isozymes may have an important role in cancer development. Some isozymes control $\mathrm{pH}$ homeostasis in tumors that appears to modulate the behaviour of cancer cells. CA XIII is the newest member of the CA gene family. It is a cytosolic isozyme which is expressed in a number of normal tissues. The present study was designed to investigate CA XIII expression in prospectively collected colorectal tumor samples.
\end{abstract}

Methods: Both neoplastic and normal tissue specimens were obtained from the same patients. The analyses were performed using CA XIII-specific antibodies and an immunohistochemical staining method. For comparison, the tissue sections were immunostained for other cytosolic isozymes, CA I and II.

Results: The results indicated that the expression of CA XIII is down-regulated in tumor cells compared to the normal tissue. The lowest signal was detected in carcinoma samples. This pattern of expression was quite parallel for CA I and II.

Conclusion: The down-regulation of cytosolic CA I, II and XIII in colorectal cancer may result from reduced levels of a common transcription factor or loss of closely linked CAI, CA2 and CAI3 alleles on chromosome 8 . Their possible role as tumor suppressors should be further evaluated.

\section{Background}

Carbonic anhydrases (CAs) are a growing family of zinccontaining metalloenzymes that have an important role in maintaining the $\mathrm{pH}$ homeostasis by catalysing the reversible hydration of carbon dioxide, $\mathrm{CO}_{2}+\mathrm{H}_{2} \mathrm{O} \leftrightarrow$ $\mathrm{HCO}_{3}{ }^{-}+\mathrm{H}^{+}$. This family includes at least twelve enzymatically active isozymes, whose subcellular localization, tis- sue distribution and kinetic properties differ. Five of the isozymes are cytosolic (CA I, II, III, VII and XIII), four are membrane associated (CA IV, IX, XII and XIV), two are mitochondrial (CA VA and $\mathrm{VB}$ ) and one is a secretory form (CA VI) [1-6]. CAs contribute to several important biological functions, such as respiration, bone resorption, 
renal acidification, gluconeogenesis and formation of cerebrospinal fluid and gastric acid $[1,7]$.

It is typical for solid tumors to create a $\mathrm{pH}$ gradient between the intracellular and extracellular compartments by acidifying the surrounding tissue to lower $\mathrm{pH}$ value than in adjacent normal tissue. Extracellular acidification has been associated with many tumor progression effects, such as loss of intercellular adhesion, increased metastasis and migration, increased rate of mutations and reduced DNA repair and upregulation of growth factors and proteases [4]. In order to maintain the $\mathrm{pH}$ gradient, tumor cells express ion transport proteins, including vacuolar $\mathrm{H}^{+}$-ATPase, $\mathrm{Cl}-/ \mathrm{HCO}_{3}$ - exchanger and $\mathrm{Na}^{+} / \mathrm{H}^{+}$exchanger $[8,9]$. Previously, lactic acid has been considered a major source of acidity in tumors [4]. More recent studies have indicated, however, that carbon dioxide also makes a significant contribution to the tumor acidity, which strongly implies to the importance of CA activity in oncogenesis. This hypothesis has been indirectly supported by the recent findings that several CA inhibitors may suppress the invasion capacity of malignant cell lines [4].

CA XIII is a novel enzyme, which is expressed in several human tissues including salivary glands, kidney, small intestine, colon, uterus and testis. Modelling of CA XIII protein revealed that is a globular molecule, and it has the highest (about $60 \%$ ) identity with cytosolic isozymes CA I, II and III. Therefore, CA XIII is clustered as cytosolic/ intracellular isoform. In the previous report, we described the production of recombinant mouse CA XIII protein, which was used in detailed activity and inhibition studies $[2,10]$. CA XIII demonstrated moderate CA catalytic activity with $k_{c a t} / K_{m}$ of $4.3 \times 10^{7} \mathrm{M}^{-1} \mathrm{~s}^{-1}$, and $k_{\text {cat }}$ of $8.3 \times 10^{4} \mathrm{~s}^{-1}$ at $25^{\circ} \mathrm{C}$ and $\mathrm{pH} 7.5$ [2]. Interestingly, CA XIII showed unique inhibitory properties compared to CA I, II and IX [10]. The clinically used sulfonamides including acetazolamide, methazolamide, dichlorophenamide, and dorzolamide demonstrated potent CA XIII inhibition, with $K_{\mathrm{i}}$ 's in the range of 17-23 nM. Another group of inhibitors, the sulfanilyl-derived compounds, obtained by reaction of aminosulfonamides with 4-acetamidobenzenesulfonyl chloride showed very potent CA XIII inhibitory properties, with $K_{\mathrm{i}}$ 's in the range of $1.3-2.4 \mathrm{nM}$, whereas these compounds were generally much less effective as inhibitors of isozymes I, II, and IX.

Different CA isozymes have become attractive targets in studies aimed at molecular mechanisms of carcinogenesis. CA IX and XII have been clearly associated with certain types of cancer [11-21]. Also cytosolic isozymes CA I and II have been investigated in some tumors including colorectal cancer $[22,23]$. Since there was no previous data on CA XIII in tumors, we collected a series of colorectal neoplasias and adjacent normal tissues, and analyzed them by an immunohistochemical staining method for the expression of this novel isozyme.

\section{Methods \\ Antibodies}

The rabbit anti-mouse/human CA XIII antibody has been described in a recent article [2]. It was raised against a synthetic peptide (AC-) DGDQQSPIEIKTKEC (-COOH). The affinity and specificity of the antibody was confirmed by ELISA titre analysis, western blotting and immunohistochemistry. In immunohistochemical staining, CA XIII has shown a distinctly different distribution pattern compared to the localization of CA I or II [2]. This finding indicates that the anti-CA XIII antibody does not crossreact with CA I or II under the present staining conditions. Rabbit antisera against human CA I and II have been produced and characterized earlier [24].

\section{Immunohistochemistry}

The normal tissue samples from the large intestine and the corresponding benign and/or malignant neoplastic samples were prospectively collected at Oulu University Hospital (Oulu, Finland). The normal samples were excised separately 20 centimeters proximally from the tumor resection site. The study was approved by the Ethics Committee of Oulu University Hospital and performed according to the guidelines of the Declaration of Helsinki.

32 distinct areas (both normal tissue and pathological lesions) of the human colorectal mucosa were examined from 12 patients. They consisted of 11 separate samples of histologically normal human colon or rectum and 17 colorectal lesions, including 6 adenomas and 11 adenocarcinomas. In 4 samples, normal tissue was found adjacent to the neoplasm and was included in the analyses. The grade of dysplasia was moderate in 3 and grave in 3 adenomas. The group of 11 malignant colorectal tumors consisted of 4 well-differentiated and 4 moderately differentiated adenocarcinomas, and 3 adenocarcinomas with a mucinous component. It should be noted that each patient had either one or more (1-3) lesions which were analyzed.

The specimens were fixed in Carnoy's fluid (absolute ethanol + chloroform + glacial acetic acid 6:3:1) for 6 hours. The samples were then dehydrated, embedded in paraffin in a vacuum oven at $58^{\circ} \mathrm{C}$, and sections of $5 \mu \mathrm{m}$ were placed on gelatine-coated microscope slides The CA isozymes were immunostained by the biotin-streptavidin complex method, employing the following steps: (a) pretreatment of the sections with undiluted cow colostral whey (Biotop Oy, Oulu, Finland) for $30 \mathrm{~min}$ and rinsing in phosphate-buffered saline (PBS), (b) incubation for 1 hr with primary antibodies diluted 1:100 in 1\% bovine serum albumin -PBS (BSA-PBS), (c) incubation for $1 \mathrm{hr}$ 
with biotinylated goat anti-rabbit IgG (Zymed laboratories inc., South San Fransisco, CA) diluted 1:300 in 1\% BSA-PBS, (d) incubation for $30 \mathrm{~min}$ with streptavidinhorseradish peroxidase (HRP) conjugate (Zymed laboratories) diluted 1:750 in PBS and (e) incubation for $2 \mathrm{~min}$ in DAB solution containing 4,5 mg 3,3'-diaminobenzidine tetrahydrochloride (Fluka, Buchs, Switzerland) in $7,5 \mathrm{ml} \mathrm{PBS}+2,5 \mu \mathrm{l} 30 \% \mathrm{H}_{2} \mathrm{O}_{2}$. The sections were washed three times for $10 \mathrm{~min}$ in PBS after incubation steps b and $c$, and four times for 5 min in PBS after step d. All the incubations and washings were carried out at room temperature. The sections were finally mounted in Neo-Mount (Merck, Darmstadt, Germany). The stained sections were examined and photographed with Zeiss Axioskop 40 microscope (Carl Zeiss, Göttingen, Germany). The intensity of immunostaining was scored on a scale of 0 to 3 as follows: 0 , no reaction; 1 , weak reaction; 2 , moderate reaction; 3 , strong reaction.

\section{Results and discussion}

Carbonic anhydrase XIII is a recently discovered enzyme, which is expressed in a number of different mammalian tissues. Structural modelling revealed that it is most closely related to cytosolic isozymes, CA I, II, and III with about $60 \%$ sequence identity, and therefore, this isozyme was clustered to the group of cytosolic/intracellular isoforms. Even though the previous paper described the distribution of CA XIII in several normal tissues, no data has been published to date on its expression in neoplastic tissues. To get a better insight into the changes in the expression levels that occur during the development of neoplasia, we analyzed both normal and pathological colorectal specimens from the same individuals.

Figures 1 and 2 show some images of CA XIII immunostaining in the colorectal tumors and normal mucosa. Reactions for CA I and II are shown for comparison. The immunostaining scoring results are shown in Figure 3. The results indicated that CA XIII immunoreactions generally follow a similar pattern with CA I and II, i.e. the signals became weaker along with increasing dysplasia and malignancy grades. There were a few exceptions, and particularly, CA II expression was relatively high in adenocarcinomas with a mucinous component, while CA I and XIII were decreased like in other adenocarcinomas (Fig. 2).

Previous studies have indicated that CA IX and XII are overexpressed in certain tumors, including colorectal adenomas and carcinomas $[18,23]$. They have been functionally linked to extracellular acidification in tumors that appears to regulate the invasive behaviour of tumor cells. Consequently, expression of CA IX has been associated with poor prognosis of some malignancies $[19,20,25,26]$. Based on the present and previous results [23], cytosolic isozymes I, II, and XIII do not probably play a significant role in the regulation of $\mathrm{pH}$ in tumors. Instead, they may be important factors for the normal intestinal physiology. This suggestion raises an important question why at least three cytosolic isozymes are expressed in the normal colorectal mucosa. Even though we cannot answer to this question at this stage, it is of interest that these CAs represent isoforms with different kinetic or inhibitory properties. CA II exhibits the highest and CA I and CA XIII moderate carbon dioxide hydratase activities [2]. Because of different biochemical characteristics, it is unlikely that all these isozymes could contribute to the same $\mathrm{pH}$ regulation process. If this was the case, one could suggest that the enzymes with low or moderate activities should represent some sort of "junk" proteins in the proteome. However, there are other possible explanations which could be considered more sound in a biological system. First, several CA isozymes have emerged during evolution, because CA enzymatic activity is required for very fundamental reactions in the body. If one isozyme was functionally defective, the others could compensate the missing one. These compensatory mechanisms would partly explain why different CA deficiencies typically produce no or only mild phenotypic changes [27-29].

Another possible role of cytosolic CAs could be linked to a hypothetical tumor suppressor function. It is notable that CA1, CA2 and CA13 genes are closely linked locating in the $\mathrm{q}$ arm of chromosome 8. Simultaneous loss of expression could result from a deletion or point mutations within regulatory regions or alleles specifying these genes. The down-regulation could also result from reduced levels of a common transcription factor. Regardless of the mechanism, three cytosolic CA isozymes are affected in colorectal tumors, and it would be tempting to propose that normal CA I, II and/or XIII proteins could have a tumor suppressor function in epithelial cells, and deletion of those alleles could be an important factor in the cascade of events contributing to colorectal carcinogenesis. Even though colorectal cancer has been associated with gain of chromosome $8 \mathrm{q}$ in a number of previous studies, and no losses have been reported [30-33], there is some evidence that $8 \mathrm{q} 21$ contains a yet unidentified tumor suppressor gene [34,35]. However, larger sets of tumors will be required to define explicitly, whether these $C A$ genes are involved in genetic alterations of colorectal tumors.

\section{Conclusion}

CA XIII expression was clearly decreased in colorectal tumors compared to the normal tissue in a pattern similar to CA I and II. Loss of expression of closely linked CA1, CA2 and CA13 genes may result from reduced levels of a transcription factor or loss of alleles specifying these genes. 


\section{Normal Adenoma Carcinoma}

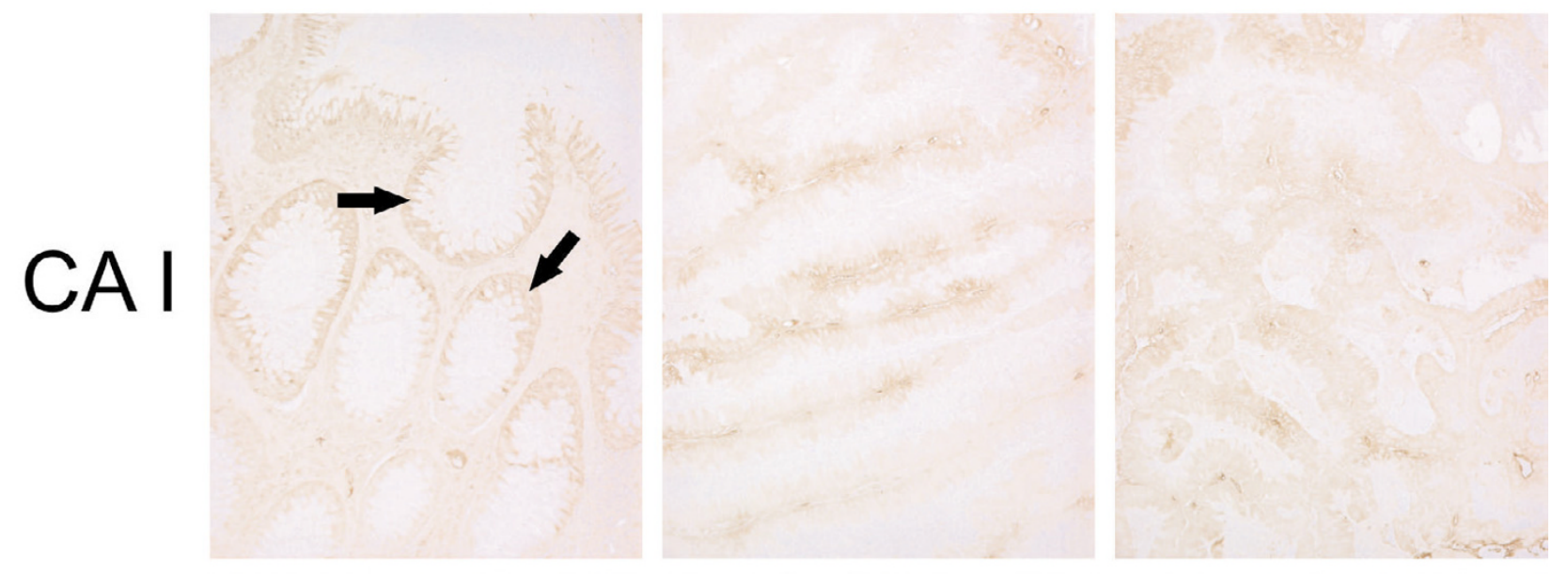

CAII

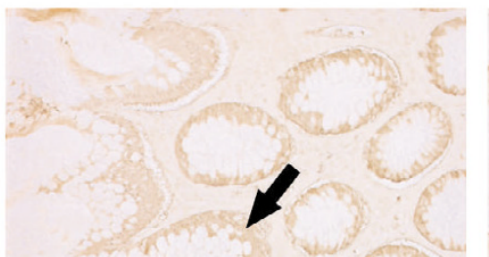

\section{CAXIII}

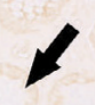

Figure I

Immunohistochemical staining of CA I, II and XIII in the normal colonic mucosa and tumors. The samples of normal mucosa, adenoma (grave dysplasia) and well differentiated adenocarcinoma were collected from one patient. The strongest immunoreaction is located in the enterocytes of the normal mucosa (arrows). Original magnification $\times 200$. 


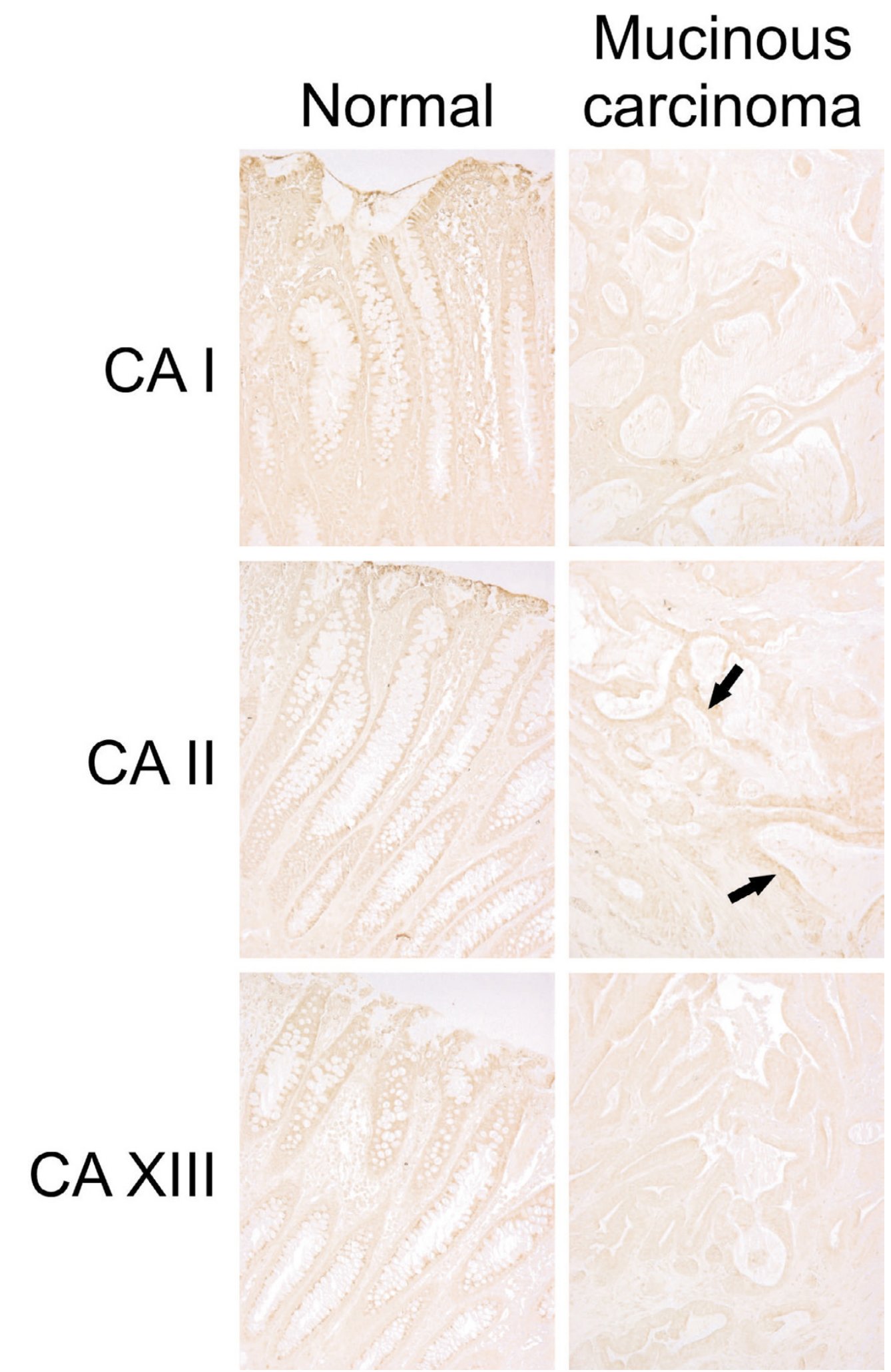

Figure 2

CA expression in the normal colonic mucosa and adenocarcinoma with a mucinous component. CA II staining intensity remained at a relatively high level in the carcinoma sample (arrows), whereas the intensities for other isozymes were decreased compared to the normal epithelium. 

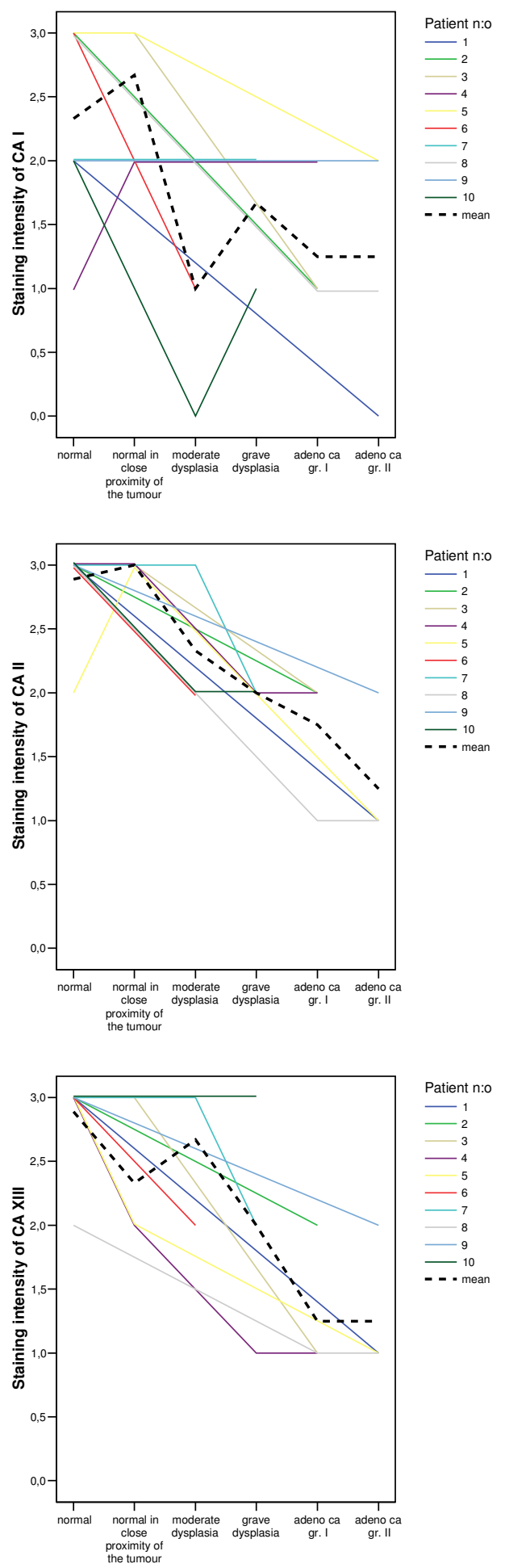

Figure 3

A graphic summary of CA immunostaining in the normal colorectal mucosa and tumor samples. The coloured lines represent the staining indices in individual patients. The dash lines indicate the mean values of staining intensity.

\section{Competing interests}

The author(s) declare that they have no competing interests.

\section{Authors' contributions}

All authors participated in the design of the study. JS, TK and AJK collected the tissue samples. LK and SP drafted the manuscript. JMH and SP characterized the antibodies. LK performed the immunohistochemical staining. LK, JK and SP analyzed the staining results. All authors read, modified and approved the final manuscript.

\section{Acknowledgements}

This work was supported by grants from Sigrid Juselius Foundation and Academy of Finland (200969).

\section{References}

I. Parkkila S, Parkkila AK: Carbonic anhydrase in the alimentary tract. Roles of the different isozymes and salivary factors in the maintenance of optimal conditions in the gastrointestinal canal. Scand J Gastroenterol 1996, 31:305-317.

2. Lehtonen J, Shen B, Vihinen M, Casini A, Scozzafava A, Supuran CT, Parkkila AK, Saarnio J, Kivela AJ, Waheed A, Sly WS, Parkkila S: Characterization of CA XIII, a novel member of the carbonic anhydrase isozyme family. J Biol Chem 2004, 279:2719-2727.

3. Mori K, Ogawa Y, Ebihara K, Tamura N, Tashiro K, Kuwahara T, Mukoyama M, Sugawara A, Ozaki S, Tanaka I, Nakao K: Isolation and characterization of CA XIV, a novel membrane-bound carbonic anhydrase from mouse kidney. J Biol Chem 1999, 274: I570I-I5705.

4. Pastorekova S, Zavada J: Carbonic anhydrase IX (CA IX) as a potential target for cancer therapy. Cancer Ther 2004, 2:245-262.

5. Shah GN, Hewett-Emmett D, Grubb JH, Migas MC, Fleming RE, Waheed A, Sly WS: Mitochondrial carbonic anhydrase CA VB: differences in tissue distribution and pattern of evolution from those of CA VA suggest distinct physiological roles. Proc Natl Acad Sci U S A 2000, 97: I677-1682.

6. Karhumaa $P$, Leinonen J, Parkkila $S$, Kaunisto $K$, Tapanainen J, Rajaniemi $\mathrm{H}$ : The identification of secreted carbonic anhydrase VI as a constitutive glycoprotein of human and rat milk. Proc Natl Acad Sci U S A 200 I, 98: I I 604-I I 608.

7. Sly WS, Hu PY: Human carbonic anhydrases and carbonic anhydrase deficiencies. Annu Rev Biochem 1995, 64:375-40I.

8. Montcourrier P, Silver I, Farnoud R, Bird I, Rochefort H: Breast cancer cells have a high capacity to acidify extracellular milieu by a dual mechanism. Clin Exp Metastasis 1997, I 5:382-392.

9. Lee $\mathrm{AH}$, Tannock IF: Heterogeneity of intracellular $\mathbf{p H}$ and of mechanisms that regulate intracellular $\mathrm{pH}$ in populations of cultured cells. Cancer Res 1998, 58:1901-1908.

10. Lehtonen JM, Parkkila S, Vullo D, Casini A, Scozzafava A, Supuran CT: Carbonic anhydrase inhibitors. Inhibition of cytosolic isozyme XIII with aromatic and heterocyclic sulfonamides: a novel target for the drug design. Bioorg Med Chem Lett 2004, | 4:3757-3762.

II. Zavada J, Zavadova Z, Pastorekova S, Ciampor F, Pastorek J, Zelnik $\mathrm{V}$ : Expression of MaTu-MN protein in human tumor cultures and in clinical specimens. Int / Cancer 1993, 54:268-274.

12. Liao SY, Brewer C, Zavada J, Pastorek J, Pastorekova S, Manetta A, Berman ML, DiSaia PJ, Stanbridge EJ: Identification of the MN antigen as a diagnostic biomarker of cervical intraepithelial squamous and glandular neoplasia and cervical carcinomas. Am J Pathol 1994, I 45:598-609.

13. McKiernan JM, Buttyan R, Bander NH, Stifelman MD, Katz AE, Chen $M W$, Olsson CA, Sawczuk IS: Expression of the tumor-associated gene MN: a potential biomarker for human renal cell carcinoma. Cancer Res 1997, 57:2362-2365.

14. Vermylen P, Roufosse C, Burny A, Verhest A, Bosschaerts T, Pastorekova S, Ninane V, Sculier JP: Carbonic anhydrase IX antigen dif- 
ferentiates between preneoplastic malignant lesions in nonsmall cell lung carcinoma. Eur Respir J 1999, I4:806-8I I.

15. Liao SY, Aurelio ON, Jan K, Zavada J, Stanbridge EJ: Identification of the MN/CA9 protein as a reliable diagnostic biomarker of clear cell carcinoma of the kidney. Cancer Res 1997, 57:2827-283I.

16. Bartosova M, Parkkila S, Pohlodek K, Karttunen TJ, Galbavy S, Mucha V, Harris AL, Pastorek J, Pastorekova S: Expression of carbonic anhydrase IX in breast is associated with malignant tissues and is related to overexpression of c-erbB2. J Pathol 2002, 197:3।4-32I.

17. Saarnio J, Parkkila S, Parkkila AK, Pastorekova S, Haukipuro K, Pastorek J, Juvonen T, Karttunen TJ: Transmembrane carbonic anhydrase, MN/CA IX, is a potential biomarker for biliary tumours. J Hepatol 200I, 35:643-649.

18. Saarnio J, Parkkila S, Parkkila AK, Haukipuro K, Pastorekova S, Pastorek J, Kairaluoma MI, Karttunen TJ: Immunohistochemical study of colorectal tumors for expression of a novel transmembrane carbonic anhydrase, MN/CA IX, with potential value as a marker of cell proliferation. Am J Pathol 1998, 153:279-285.

19. Giatromanolaki A, Koukourakis MI, Sivridis E, Pastorek J, Wykoff CC, Gatter KC, Harris AL: Expression of hypoxia-inducible carbonic anhydrase-9 relates to angiogenic pathways and independently to poor outcome in non-small cell lung cancer. Cancer Res 200I, 6I:7992-7998.

20. Chia SK, Wykoff CC, Watson PH, Han C, Leek RD, Pastorek J, Gatter KC, Ratcliffe P, Harris AL: Prognostic significance of a novel hypoxia-regulated marker, carbonic anhydrase IX, in invasive breast carcinoma. J Clin Oncol 200I, 19:3660-3668.

21. Wykoff CC, Beasley NJ, Watson PH, Turner KJ, Pastorek J, Sibtain A, Wilson GD, Turley H, Talks KL, Maxwell PH, Pugh CW, Ratcliffe PJ, Harris AL: Hypoxia-inducible expression of tumor-associated carbonic anhydrases. Cancer Res 2000, 60:7075-7083.

22. Mori M, Staniunas RJ, Barnard GF, Jessup JM, Steele GDJ, Chen LB: The significance of carbonic anhydrase expression in human colorectal cancer. Gastroenterology 1993, 105:820-826.

23. Kivela AJ, Saarnio J, Karttunen TJ, Kivela J, Parkkila AK, Pastorekova S, Pastorek J, Waheed A, Sly WS, Parkkila TS, Rajaniemi H: Differential expression of cytoplasmic carbonic anhydrases, CA I and II, and membrane-associated isozymes, CA IX and XII, in normal mucosa of large intestine and in colorectal tumors. Dig Dis Sci 200I, 46:2179-2I86.

24. Parkkila AK, Parkkila S, Juvonen T, Rajaniemi H: Carbonic anhydrase isoenzymes II and I are present in the zona glomerulosa cells of the human adrenal gland. Histochemistry 1993, 99:37-4I.

25. Koukourakis MI, Giatromanolaki A, Sivridis E, Simopoulos K, Pastorek J, Wykoff CC, Gatter KC, Harris AL: Hypoxia-regulated carbonic anhydrase-9 (CA9) relates to poor vascularization and resistance of squamous cell head and neck cancer to chemoradiotherapy. Clin Cancer Res 200I, 7:3399-3403.

26. Hoskin PJ, Sibtain A, Daley FM, Wilson GD: GLUTI and CAIX as intrinsic markers of hypoxia in bladder cancer: relationship with vascularity and proliferation as predictors of outcome of ARCON. Br J Cancer 2003, 89: I 290-I 297.

27. Kendall AG, Tashian RE: Erythrocyte carbonic anhydrase I: inherited deficiency in humans. Science 1977, 197:47|-472.

28. Kim G, Lee TH, Wetzel P, Geers C, Robinson MA, Myers TG, Owens JW, Wehr NB, Eckhaus MW, Gros G, Wynshaw-Boris A, Levine RL: Carbonic anhydrase III is not required in the mouse for normal growth, development, and life span. Mol Cell Biol 2004, 24:9942-9947.

29. Ortova Gut MO, Parkkila S, Vernerova Z, Rohde E, Zavada J, Hocker M, Pastorek J, Karttunen T, Gibadulinova A, Zavadova Z, Knobeloch KP, Wiedenmann B, Svoboda J, Horak I, Pastorekova S: Gastric hyperplasia in mice with targeted disruption of the carbonic anhydrase gene Car9. Gastroenterology 2002, I 23:I889-1903.

30. Diep CB, Teixeira MR, Thorstensen L, Wiig JN, Eknaes M, Nesland JM, Giercksky KE, Johansson B, Lothe RA: Genome characteristics of primary carcinomas, local recurrences, carcinomatoses, and liver metastases from colorectal cancer patients. Mol Cancer 2004, 3:6.

31. Douglas EJ, Fiegler H, Rowan A, Halford S, Bicknell DC, Bodmer W, Tomlinson IP, Carter NP: Array comparative genomic hybridi- zation analysis of colorectal cancer cell lines and primary carcinomas. Cancer Res 2004, 64:4817-4825.

32. Richter H, Slezak P, Walch A, Werner M, Braselmann H, Jaramillo E, Ost A, Hirata I, Takahama K, Zitzelsberger H: Distinct chromosomal imbalances in nonpolypoid and polypoid colorectal adenomas indicate different genetic pathways in the development of colorectal neoplasms. Am J Pathol 2003, 163:287-294.

33. Aragane H, Sakakura C, Nakanishi M, Yasuoka R, Fujita Y, Taniguchi $\mathrm{H}$, Hagiwara A, Yamaguchi T, Abe T, Inazawa J, Yamagishi H: Chromosomal aberrations in colorectal cancers and liver metastases analyzed by comparative genomic hybridization. Int J Cancer 2001, 94:623-629.

34. Varon R, Gosse-Brun S, Bignon YJ, Sperling K, Uhrhammer N: Nijmegen breakage syndrome gene (NBSI) is not the tumor suppressor gene at 8q21.3 involved in colorectal carcinoma. Oncol Rep 2002, 9:709-71I.

35. Uhrhammer N, Bay JO, Gosse-Brun S, Kwiatkowski F, Rio P, Daver A, Bignon YJ: Allelic imbalance at NBSI is frequent in both proximal and distal colorectal carcinoma. Oncol Rep 2000, 7:427-431.

\section{Pre-publication history}

The pre-publication history for this paper can be accessed here:

http://www.biomedcentral.com/1471-2407/5/41/prepub
Publish with Bio Med Central and every scientist can read your work free of charge

"BioMed Central will be the most significant development for disseminating the results of biomedical research in our lifetime. "

Sir Paul Nurse, Cancer Research UK

Your research papers will be:

- available free of charge to the entire biomedical community

- peer reviewed and published immediately upon acceptance

- cited in PubMed and archived on PubMed Central

- yours - you keep the copyright

Submit your manuscript here:

http://www.biomedcentral.com/info/publishing_adv.asp 